\title{
Glacial flutings in bedrock, an observation in East Greenland
}

SVEND FUNDER

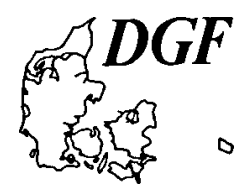

Funder, S.: Glacial flutings in bedrock, an observation in East Greenland. Bull. geol. Soc. Denmark, vol. 27, pp. 9-13. Copenhagen, October 1st 1978. https://doi.org/10.37570/bgsd-1978-27-02

\begin{abstract}
Large scale glacial flutings cover an area of $4 \times 1.5 \mathrm{~km}$ on the northern shore of Harefjord in the interior Scoresby Sund fjord complex. The flutings are modelled in coarse sandstone and conglomerates, a few small features are probably composed of till. The ridges measure up to $2000 \mathrm{~m}$ in length and $5 \mathrm{~m}$ in height and occur between 50 and $250 \mathrm{~m}$ above sea level in the gently sloping lowland area adjacent to the fjord. They were probably formed beneath the lateral part of the former Harefjord-Glacier which receded rapidly in the fjord and exposed the area at c. 7500 years BP.

Large scale glacial flutings have not been recorded before in Greenland, but seem to be of common occurrence in parts of North America. They have probably been formed near the margin of actively moving glaciers, and secondary flow in the basal ice may have played an important role.
\end{abstract} S. Funder, Geologisk Museum, Oster Voldgade 5-7, DK-1350 Copenhagen K, Denmark, September 9th,
1977.

During field work in the interior Scoresby Sund fjord complex in East Greenland a peculiar type of landscape consisting of straight parallel ridges and grooves was encountered. The ridges and grooves were mainly modelled in the local bedrock, the Røde $\varnothing$ Conglomerate, and were diagnosed as glacial flutings, - a type of landform belonging to the family of 'stream line molded forms' (Flint 1971: 100), and distinguished from drumlins by their larger length/breadth ratio and lack of proper 'stream lining'.

Large scale glacial flutings have not previously been observed in Greenland, and the occurrence will here be briefly described and discussed.

\section{Description}

The flutings are located at Kullerne, a gently undulating lowland area at the north side of Harefjord and occur between 50 and $250 \mathrm{~m}$ above sea level. The fluted area measures $4 \times 1.5 \mathrm{~km}$ and comprises up to 50 parallel ridges (fig. 1). The ridges are 50 to $2000 \mathrm{~m}$ long and $1-5 \mathrm{~m}$ high. Their crest lines are smooth and conform with the general topography in the area; the wave length, i.e. the distance between neighbouring ridge crests, averages $45 \mathrm{~m}$. In stream cut sections the grooves between the ridges can be seen to form a negative of the ridges (fig. 2).

The large majority of ridges are composed of the local type of bedrock, the Røde $\varnothing$ Conglomerate, which is exposed at their surface. Erratic boulders occur abundantly on the ridges (fig. 3), and in places the conglomerate surface has been hidden beneath a veneer of loose till. Between the conglomerate ridges a few significantly smaller ridges have been observed which by excavation seemed to be composed entirely of till (fig. 4). These ridges measure $1-1.5 \mathrm{~m}$ in height, $75 \mathrm{~m}$ in length and only two were observed (fig. 1).

The ridges and grooves trend $112^{\circ}$, parallel to the general direction of the fjord and to the direction of movement of the former fjord glacier. However, glacial striations which can be seen on the ridges at a few localities show varying directions of ice movement; on the north side of the ridges the striation was parallel to the ridge trend, while on the south side and over the crest it deviated by $20^{\circ}$, running east-west at $90^{\circ}$. No crossing striae were observed, neither was there any evidence of a gradual transition between the two directions. It is uncertain whether the two sets of striae are contemporaneous and contemporaneous with the formation of the flutings.

\section{Geology and deglaciation}

The fluted surface coincides with an isolated occurrence of the Røde $\varnothing$ Conglomerate in an area of Pre-Cambrian metamorphic rocks. The Røde 


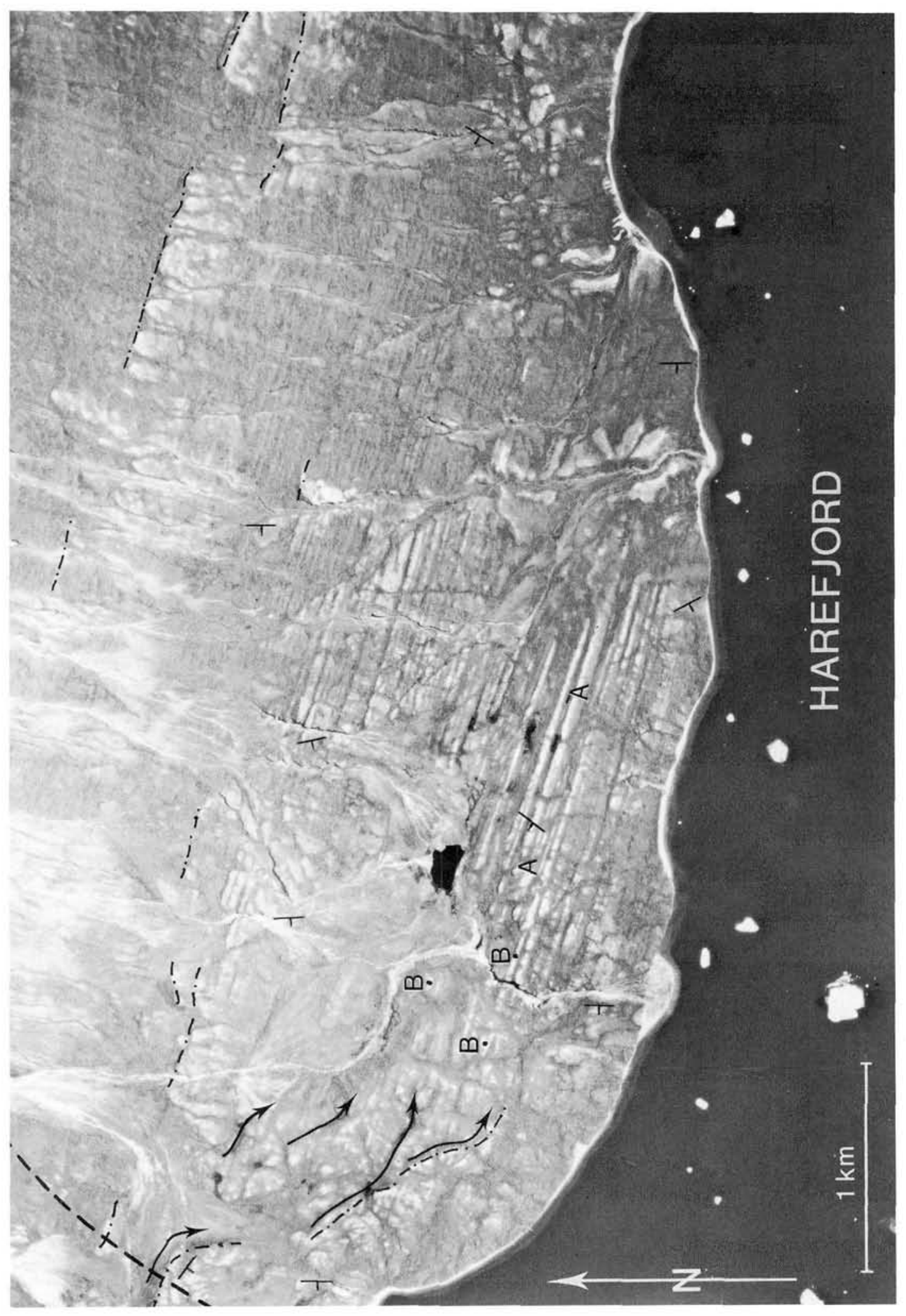


Fig. 1. Glacial flutings at Kullerne. A: till flutings. B: sites with well preserved glacial striae. Thick broken line: boundary between gneiss to the west and Røde $\emptyset$ Conglomerate to the East (after Collinson 1972). The strike and dip of conglomerate beds are indicated (Collinson, unpublished field maps). Thin dotted lines: kame terraces. Arrows: glacial melt water channels. (Reproduced with permission from the Geodetic Institute, No. $371 / 71)$.

$\varnothing$ Conglomerate is a formation of coarse sandstone and conglomerates with gneiss phenoclasts and may have been deposited during a period of faulting activity in the Lower Permian (Collinson 1972). The sandstone and conglomerate beds show varying orientations within the area (fig. 1) and may represent several depositional cones. Thus although the formation of the flutings probably was dependant on some general physical properties in the conglomerate there is no relation between the conglomerate structures and the trend of the flutings.

According to $\mathrm{C}-14$ datings Harefjord and the lowland area along its shores were deglaciated at c. 7500 years BP during a period of rapid glacier shrinkage, the rate of recession being to some extent determined by the local topography (Funder 1972). Series of kame terraces on the mountain sides above the flutings reflect successive sta- ges in this recession. In the western part of the area these ice margin features cut across the flutings which have been hidden under glacifluvial gravel or eroded by glacial melt water.

\section{Discussion}

Fluted surfaces cover large areas especially in the formerly glaciated lowland areas of North America (e.g. Bird 1967; Flint 1971). Most frequently the flutings are composed of unconsolidated sediments, till and stratified deposits; but bedrock flutings similar to those described here occur abundantly at least in some areas, e.g. in the Mackenzie Valley where they were formed in Palaeozoic and Mesozoic limestone, shale and sandstone (Smith 1948). From northern Alberta Gravenor \& Meneley (1958) reported flutings in granitic gneiss and porphyritic granite.

From a genetic point of view it may be useful to distinguish the large scale features described here from the small scale flutings which occur in fresh till in front of existing glaciers. The latter type may have been formed by the squeezing of till from the substrate into linear subglacial tunnels

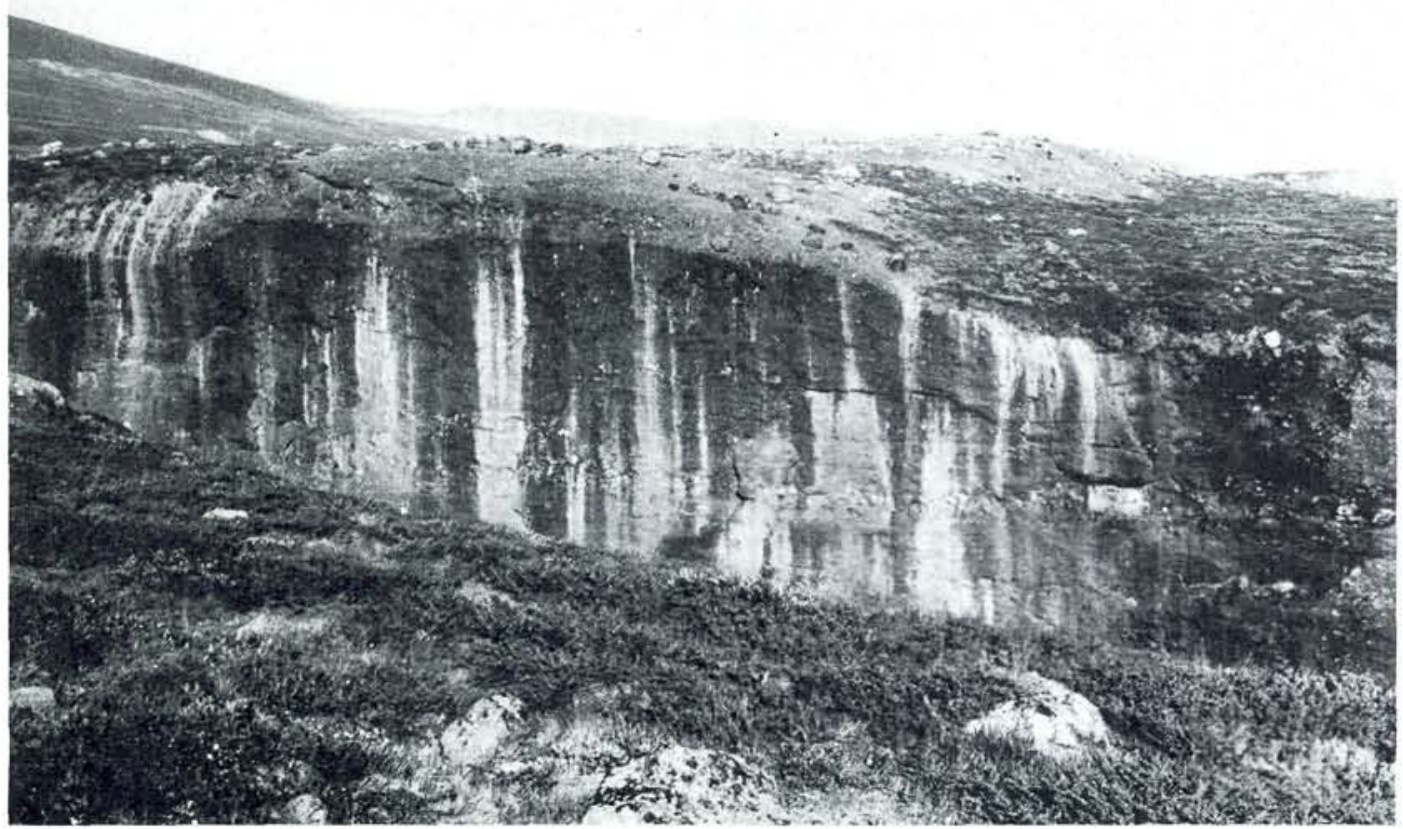

Fig. 2. Stream cut section through a ridge and a groove. 


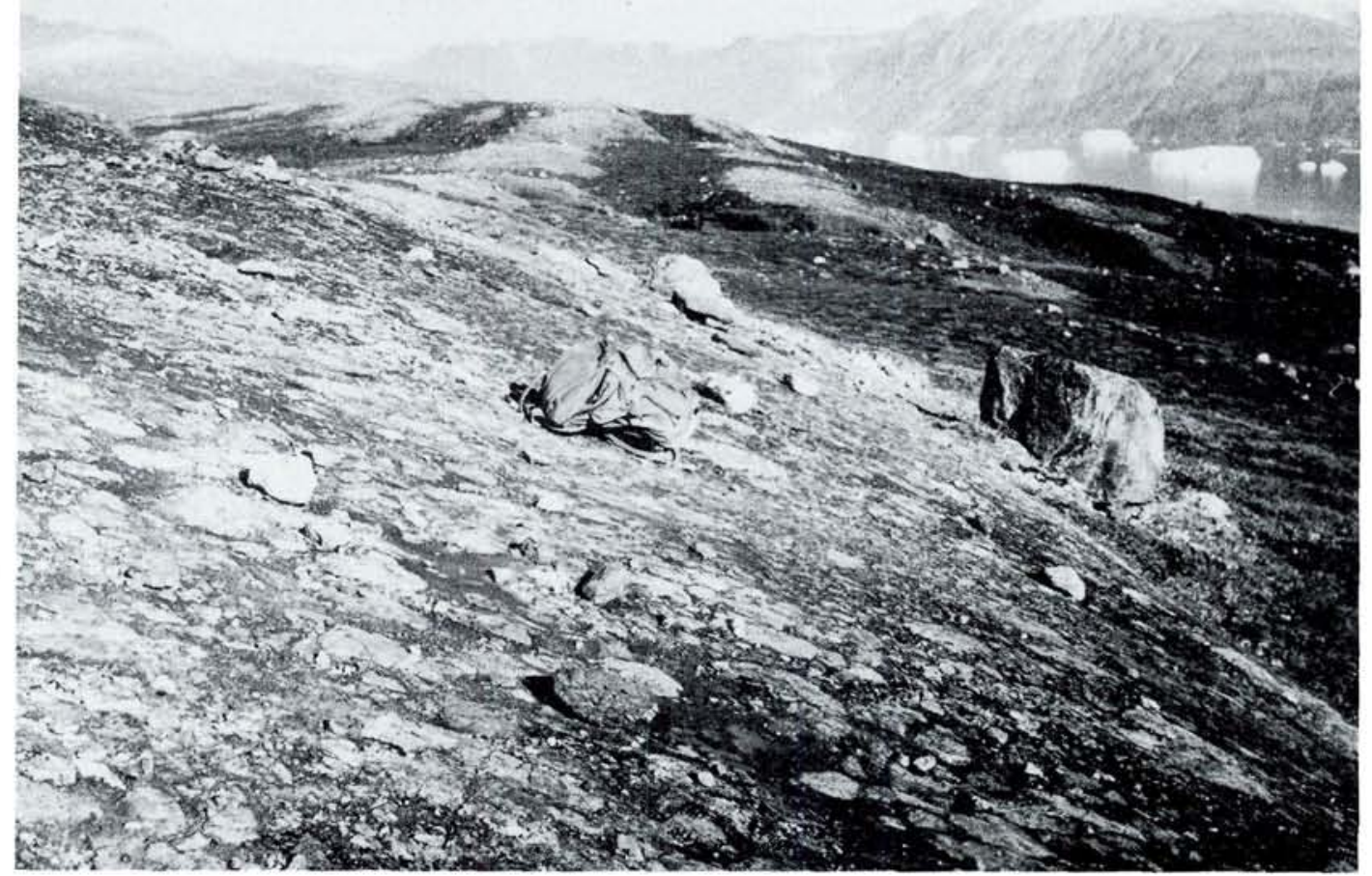

Fig. 3. Fluting ridge with exposed conglomerate. Glacial striation

is preserved in the surface of the phenoclasts.

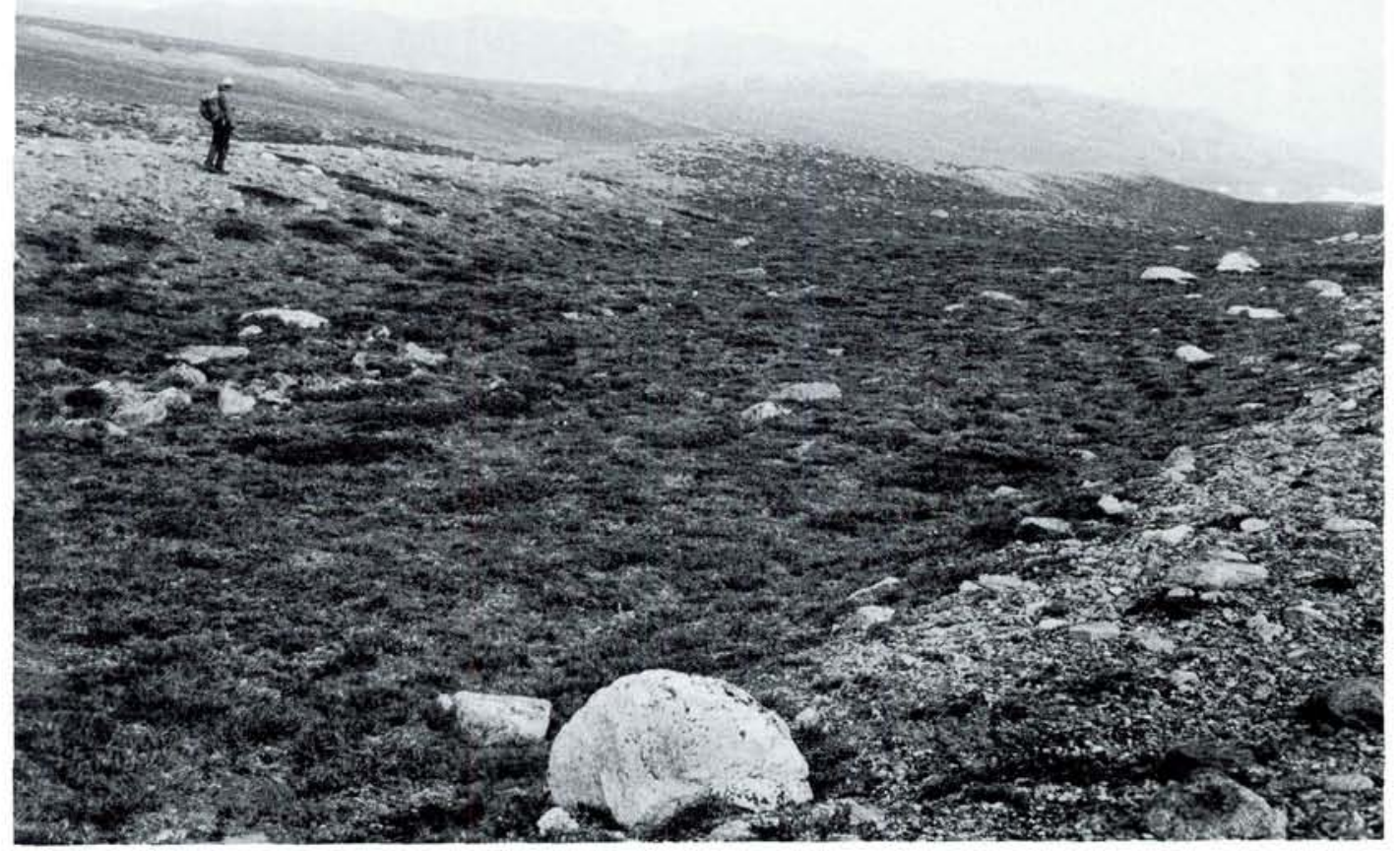

Fig. 4. Fluting ridge composed of till. 
which were formed in the lee of large boulders or bedrock knobs when the glacier ice moved past them (e.g. Hoppe \& Schytt 1953).

To account for the large scale flutings, with a regular wave length and ridges up to $20 \mathrm{~km}$ long, secondary flow in the basal ice perpendicular to the trend of the ridges has been suggested (e.g. Gravenor \& Meneley 1958; Shaw 1975). To operate the lateral transport of material in the ice, or the rhythmic variation in the intensity of erosion, Shaw (1975) invoked ice flow in tubular vortices, which could possibly be generated by the lateral pressure gradient arising from longitudinal crevassing in the glacier.

For the East Greenland flutings described here it seems that the association between flutings and the occurrence of the Røde $\varnothing$ Conglomerate could indicate a relationship between physical properties in the substrate and fluting formation. The striations observed on some ridges could possibly be interpreted to show the existence of secondary flow in the ice during the period of fluting formation. Finally, the extreme rareness of large scale glacial flutings in Greenland show that, whatever their explanation, suitable conditions for their formation were seldom achieved.

Acknowledgements. The director of the Geological Survey of Greenland is acknowledged for permission to publish these results.

\section{Dansk sammendrag}

En mærkelig landskabsform er iagttaget i området Kullerne ved Harefjord i det indre Scoresby Sund, Østgrønland. Landskabet består af lange parallelle rygge med mellemliggende dale. Ryggene kan nå en højde af $5 \mathrm{~m} \mathrm{og} \mathrm{en} \mathrm{længde} \mathrm{på} 2 \mathrm{~km}$, omkring 50 rygge ligger ved siden af hinanden med en indbyrdes afstand på $45 \mathrm{~m}$ og dækker et areal på 4,5 × 1,5 km. Ryggene er uderoderet i Røde $\varnothing$ Konglomerat, en serie af grove sandsten og konglomerater, der formodentlig er afsat i Perm. Der er ingen forbindelse mellem strukturer i Røde $\emptyset$ Konglomeratet og retningen af rygge og dale, men disse løber parallelt med den nærliggende Harefjord, og dermed med den sidste gletscherbevægelse i området for 7500 år siden.

Landskabsformen er diagnosticeret som 'glaciale rifler' (glacial flutings), en terranform, der ikke tidligere er påvist $i$ Grønland, men som dækker store områder i Nordamerika. Hvorledes 'riflede' landskaber dannes er ikke fastslået med sikkerhed. Sandsynligvis dannes de $\mathrm{j}$ en zone bag isens rand. De rytmiske svingninger $i$ iserosionens intensitet, som ryggene er udtryk for, har varet forklaret ved forekomsten af liggende hvirvelstrømsbevægelser $i$ gletscherisens nedre deI.

\section{References}

Bird, J. B. 1967: The physiography of Arctic Canada. Baltimore: Johns Hopkins. 336 pp.

Collinson, J. D. 1972: The Rode $\emptyset$ Conglomerate of inner Scoresby Sund and the Carboniferous (?) and Permian rocks west of the Schuchert Flod. Meddr Grenland 192, 6: 48 pp. (also Bull. Gronlands geol. Unders. 102).

Flint, R. F. 1971: Glacial and Quaternary geology. New York: Wiley. 892 pp.

Funder, S. 1972: Deglaciation history in the fjords of Scoresby Sund. Spec. publs Inst. Br. Geogr. 4: 33-43.

Gravenor, C. P. \& Meneley, W. A. 1958: Glacial flutings in central and northern Alberta. Amer. J. Sci. 256: 715-728.

Hoppe, G. \& Schytt, V. 1953: Some observations of fluted moraine surfaces. Geogr. Annl 35: 105-115.

Shaw, J. 1975: The formation of glacial flutings. Bull. roy. Soc. New Zealand 13: 253-258.

Smith, H. T. U. 1948: Giant glacial grooves in northwest Canada. Amer. J. Sci. 246: 503-514. 